\title{
Informational Technologies as a Tool for Local Level Sustainable Development Goals Implementation
}

\author{
Liubov V. Zharova ${ }^{i}$ IeVGen V. KhLOBYstovii
}

The research represents the interdisciplinary approach for sustainable development of local communities through the implementation latest innovative approaches and closing the gaps by modern technological possibilities. The paper proposes methodological approaches for informational and analytical support for decision-making on sustainable development of local territorial entities (for example, united territorial communities, BTSEE). It is emphasized that the climate change forecast must be implemented to local, territorial development strategies. The central hypothesis of this research is that the competitiveness and efficiency of economic development local communities can be reached in the framework of combating climate changes with the implementation of information technologies on all steps - from planning until realization. It emphasized that the climate change forecast must be implemented to local, territorial development strategies. The way of implementation is that the territorial development strategies take into account changes in the functional purpose of the territories and determine the directions of prospective activity, taking into account changes in agro-climatic and infrastructural conditions of development. For this purpose, it is proposed to create a complex of information and analytical support for the sustainable development of local, territorial entities. The permissible value of the reverse subsidy, according to our calculations, should be no more than $25 \%$. It was demonstrated that it is possible to enable the sustainable development of financially capable communities if a flexible, financially based approach is used to determine the reverse subsidy's amount. Implementing the proposed mechanisms for the sustainable development of the BTSEE involves active consultation with local leaders and government representatives in charge of government decentralization.

Keywords: green economics, sustainable development goals, economics tendencies, decentralization, international economic.

Introduction. The interdisciplinary format of research today is more necessary than the modern approach. Nowadays, the complexity, ambiguity, and vulnerability of life (more known as VUCA concept of the world) dictate the new rules and create new limits for development. Even our understanding of development is changing. We become more aware of the social and environmental aspects of our lives. These aspects cannot be separated from economic life. Sustainable development (SD), as possibly finding the best solution of the classical economic tradeoff between efficiency and equity in the long run (the long run, in this case, can be estimated like continued development of humanity) represents more survival strategies than the modern concept of development. Sustainable development goals (SDG) are actively implemented in all spheres of life. Moreover, the idea of sustainability creates the

\footnotetext{
${ }^{i}$ Liubov V. Zharova, Dr. (Economics), Head of Department of International Economic Relations, Management \& Business at Concordia Ukrainian-American University, Kyiv; professor at University of Economics and Humanities, Poland, Bielsko-Biala;

${ }^{i i}$ Ievgen V. Khlobystov, Dr. (Economics), Professor, Professor of Department of Environmental Studies, National University of Kyiv-Mohyla Academy; professor at University of Economics and Humanities, Poland, Bielsko-Biala.

(c) L. V. Zharova, Ie. V. Khlobystov, 2021.

https://doi.org/10.21272/mer.2021.92.01
}

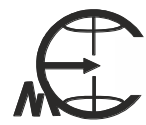




\section{Л. В. Жарова, С. В. Хлобистов.}

Інформаційні технології як інструмент реалізації Цілей сталого розвитку на місцевому рівні

platform for cooperation and building up a new world. In this context, several problems arise (they are not unique, but in the framework of this research, we will focus on Ukraine):

Efforts primarily focused on the governmental level, while the local communities were developing actively but not necessarily sustainable.

Strategic approaches and drawing up documents often focused on traditional economic methods that made them less universal.

The research about the urgency of new approaches development and rising intersectionality of research is actually and highly demanded in the framework.

\section{Informational technologies for measuring development}

Generally speaking, information technology (IT) involves developing, maintaining, and using computer systems, software, and networks to process and distribute data.

The World Economic Forum attempted to connect IT with economic development at the beginning of the fourth industrial revolution, as they announced. The Networked Readiness Index (NRI), referred to as Technology Readiness, measures the propensity for countries to exploit the opportunities offered by information and communications technology (ICT). Research results were presented in a series of annual Global Information Technology Report that was stopped issuing from 2017.

The research was built upon six principles [1]:

1) a high-quality regulatory and business environment is critical to leverage ICTs and generate impact fully;

2) ICT readiness - as measured by ICT affordability, skills, and infrastructure is a precondition to generating impact;

3) Fully leveraging ICTs requires a society-wide effort: the government, the business sector, and the population at large each have a critical role to play;

4) ICT use should not be an end in itself. The impact that ICTs have on the economy and society is what ultimately matters;

5) the set of drivers - the environment, readiness, and usage - Interact, coevolve, and reinforce each other to form a virtuous cycle; and

6) the networked readiness framework should provide clear policy guidance.

Country's profiles analysis show that that new era was nurtured by a different type of innovation, increasingly based on digital technologies and on the new business models it allows. In recent years, digital innovation has been primarily driven by consumer demand, which means that it could be addressed to business and governmental issues.

The top countries (Finland, Switzerland, Sweden, Israel, Singapore, the Netherlands, and the United States) have different social, cultural and historical backgrounds. Still, all of them are characterized by very high levels of business IT adoption. This technology-enabled innovation, in turn, unleashes new competitive pressures that call for yet more innovation by tech and non-tech firms alike.

Ukraine in this ranking placed 64 from the 139 with characteristics represented in figure 1.

The represented data illuminate that we have problems or, more correct - gaps that could be overcome by applying IT. There are, in most cases, connected with governance and regulation. This means that this sphere mainly needed new approaches on all levels - country, region, and local $[2,3,4]$.

\section{Focus on sustainable development}

Sustainable development goals included a wide range of issues that are actual nowadays. As we mentioned before, it's become the new basis for strategic, political, governance and entrepreneurial activities [5]. However, in the limits of this research, we will concentrate on goal 13 . 
Liubov V. Zharova, Ievgen V. Khlobystov. Informational Technologies as a Tool for Local Level Sustainable Development Goals Implementation

Goal 13 foresees the implementation of measures to prevent and adapt to climate change that affect different levels of territories and communities that is highly represented in the numerical research (see [6-10]. There is an urgent need for a basic territorial level of adaptation to climate change (more territorial adaptation solutions in works [11-15]).

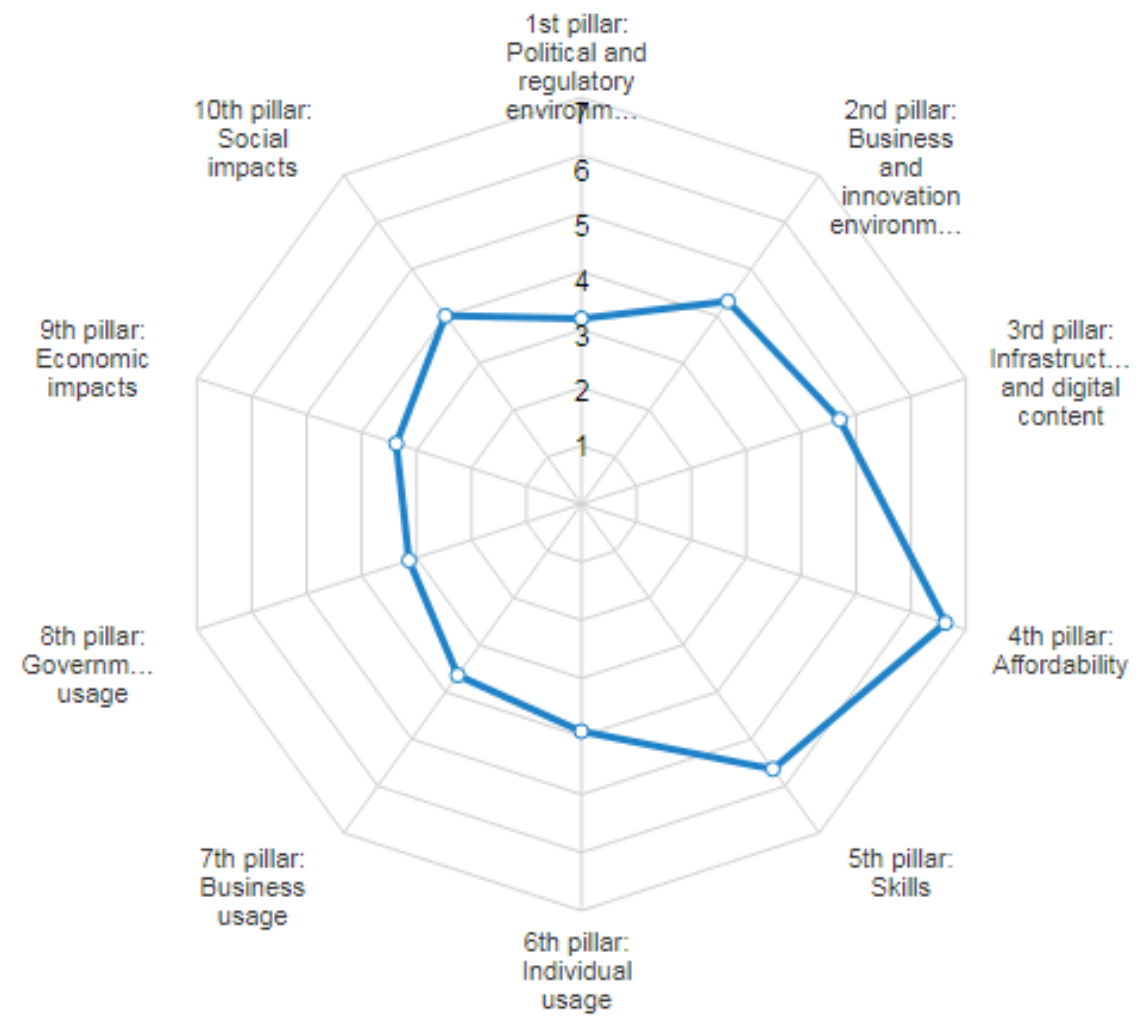

Figure 1. Ukraine in the Global Informational Technology Report [1]

Adaptation measures are conditioned and determined by the effectiveness of plans, policies and programs relating to the various aspects of managing the territories and the level of use of natural resources $[16,17]$.

The effects of global climate change are being monitored in Ukraine in reducing the water content of small and medium-sized rivers, in the dry periods in the summer, in the continuation of the warm period from autumn to November, and in gradually changing agroclimatic conditions. This means that, for local, territorial groups, it is time to create climate programs that should rely on information and analytical support for the most vulnerable activities and resources. We define vulnerability as a response to irreversible changes due to changes in conditions and factors of life and economic processes. These are local resources for the united communities in Ukraine, including agriculture and water and transport infrastructure. The ability to quantify these resources, their availability in statistical reporting, and the clustering (combination) of Eastern resource utilization, allows us to assess the strategic capacity to adapt to climate change $[18,19,20]$. 


\section{Practicies and Problems on Local Level}

Basic territorial self-sufficient entities (BTSSEs) are the leading local territorial units of the administrative system; in Ukraine, it is the united territorial communities (UTC); in Poland, it is the powiats and gminas.

We are identifying basic territorial entities for three main reasons:

1. Managerial needs;

2. Effective economic and social development;

3. Efficient use of territory resources.

More detailed analysis shows that with the theoretical perspective, we should consider that the essence of mentioned territorial allocation is related to the search for the most effective mechanisms of territorial governance. We define BSTEE as the fundamental local, territorial administrative unit, which functions as self-government and financial self-sufficiency, which can implement these functions to achieve sustainable territorial development. BSTEE allocation is motivated by two factors.

Natural resources have certain limitations and ambiguous advantages in the long term and partially in the medium-term period. Hence, according to studies on the dynamics of arable land use and crop structure, the increase in land use in the direction of least value-added is associated with high returns, but only in the short term. In particular, sunflower and rapeseed crops have increased by $5 \%$ over the last four years. However, the profitability of such activities has a declining trend. According to the researches of G. Studinska, it creates a minor benefit. Let's evaluate the rating of Ukraine by the level of brands. We can say that the absence of brands or the isolation of brands in the domestic market could be interpreted as a sign of low economic development. Traditionally, branding results from commercial initiatives and public concern (such as stimulation, encouragement, education). Brands should be a source of economic activity and capitalization. Therefore, it is advisable to clarify and actively promote brands in both domestic and foreign markets.

The development of BTSEE foresees an increase in the effectiveness and efficiency of environmental policy, especially in areas sensitive to the environment. Determining the economic levers to increase greening the economy becomes more and more relevant at the local level. In particular, by encouraging expert research to institutionalize initiatives and create the preconditions for a positive stakeholder image.

The significant role in the development of BTSEE is to determine the perspective signposts for economic growth as a sphere of efforts in designing, programming and policymaking. This allows the industry that forms the economic "profile" of BTSEE to become the basis. That is one that has prospects for development for 10-15 years. Hence, tourism could be interpreted as an industry characterized by high return on capital, rapid turnover of money. Still, more or less continuous profitability requires several years of operating, while agricultural enterprises will make a profit for the following year. Consequently, the combination of short-term areas of profitability and strategic prospects is the clue to the sustainable development of BTSEE.

Underline, the aim of forming BSTEE is to identify the species of these entities, their functions, and the possibility of implementing effective local policies on a sustainable development basis. Localization of sustainable development policy is a general practice in EU member states; the Netherlands, Germany, Sweden, and Poland have an exciting and useful experience. The specificity of the whole system of local self-government in Poland is based on the principle of supplementation rather than absorption. That means that each successive level of self-government performs only those functions that cannot perform lower ones. They are also based on clear and understandable criteria for allocating territories, procedures, and responsibilities. 
Liubov V. Zharova, Ievgen V. Khlobystov.

Informational Technologies as a Tool for Local Level Sustainable Development Goals Implementation

One of the possible solutions for increasing the effectiveness of local, sustainable development policy and implementing their sustainable development goals is to stimulate and enforce green start-ups and projects to meet the challenges of economic development and combat climate changes [21,22].

The Ukraine 2020 Sustainable Development Strategy - the framework document for the development of sustainable development initiatives - developed in particular because of the Association Agreement between Ukraine, on the one hand, and the European Union, the European Atomic Energy Community, and their Member States. The analysis of the main issues mentioned in this document, as well as the analysis of the experience of decentralization processes in the country, allowed identifying priority directions for the development of BTSEE at the level of community and business [23].

In the framework of the analysis of the experience of decentralization in Ukraine, data of the Organization for Economic Cooperation and Development elt to identify possible directions for improving the effectiveness of local, sustainable development policy (BTSEE):

- Organization of communication with local entrepreneurs and collaboration with large companies operating in the territory based on the use of a cluster approach (or creating a cluster as a geographical concentration of similar, related or additional enterprises with active channels for business transactions, communications and dialogue sharing specialized infrastructure, labor markets and services, and share opportunities or threats);

- Stimulation of participation in various events (programs, fairs, meetings) to develop territories of common interest, initiated by the association, by the state, the EU, etc. Such communications at high-level meetings are needed to agree on goals and goals for business development, identify key actors to support the goals set, share experience and experience;

- Inspiration civic activism, education and outreach activities, fostering a culture of sustainability and society's demand for transparency, a clean environment, and social responsibility. Also, close cooperation in the form of dialogue with residents and entrepreneurs and managers of territorial associations will adequately assess the current skills needs for the development of small and medium-sized businesses, as well as cooperation with large (regional or national) employers and the Universities and will give impetus to the development of institutions, professional education;

- Stimulating the development of start-ups, including training, the creation of incubators, etc. Poland and Ukraine need to increase their English language skills, free access to best practices and equal participation in international experience and discussion.

Undoubtedly, the most effective financial support for regional (communities) development remains open to Ukraine, as discussed in numerous documents and studies on territorial expansion, especially in regional support that is not currently attractive for investment.

One of the possible ways to estimate and solve mentioned problems can be smoothing local budgeting through intergovernmental transfers, particularly the use of reverse subsidies. Let us take a closer look at this problem.

In the current conditions of decentralization, the problem of developing an effective system of managing the finances of territorial communities becomes especially relevant. Due to the adoption of amendments to the Tax Code of Ukraine and the Budget Code of Ukraine, the financial capacity of local self-government has been significantly expanded.

Reform experience showed that as early as the first phase in 2015 , only $6.8 \%$ of city, town and village councils voluntarily joined together. More than $10 \%$ of the united territorial communities created in 2015 had a population of less than 3.000, which casts doubt on their self-worth capacity.

In January-September 2016, creating united communities slowed down, with only $8.1 \%$ of 
city, town, and village councils covering the unification process. In the fiscal year 2016, some financial incentives for the united territorial communities were implemented through targeted subventions for the formation of community infrastructure according to the developed plans for their socio-economic development and the funds of the State Regional Development Fund. All the united territorial communities in which elections took place on October 25, 2015, entered into direct intergovernmental budgetary relations in the fiscal year 2016 [24].

Changes to the Budget and Tax Codes have made practical steps towards fiscal decentralization, significant changes in intergovernmental budgetary relations, and replenishment of local budgets due to the redistribution of sources of tax revenues between different levels of the system. However, a more detailed analysis of the possible consequences of implementing some mechanisms indicates that they also hinder the development of BTSEE and threaten their financial capacity.

Thus, the size of the subsidy for the formation of the BTSEE infrastructure is an estimated amount, depending on the area of the BTSEE territory and the size of the rural population living in the territory. Consequently, BTSEE, which includes rural and urban areas, does not receive funding for the development of urban infrastructure that impedes community development.

The other two subventions - for the implementation of measures for the socio-economic development of individual territories and the funds of the Federal State Budget Fund - depend on the decisions of the special commission created under the relevant ministry, which is the main manager of these funds. This indicates that subjectivism is present in the process of granting them. In addition, they are provided not only to local territorial communities but also to regional, rayon budgets and cities of oblast significance.

In 2014, the Verkhovna Rada adopted amendments to the Budget Code. The balancing system was replaced by the budgetary equalization system, which provides for horizontal equalization of the territorial taxability depending on the level of income per inhabitant achieved by the introduction of the primary and reimbursement mechanism.

The mechanism for financing environmental activities is also ineffective. Among the problems that need to be addressed by the managerial influence are the following: improvement of the means of use of the environmental tax (it is constantly received only by the BTSEE in the territory of which large industrial enterprises are located); introduction of the mechanism of accumulation of environmental tax funds for their efficient use for the intended purpose; ensuring that a portion of the tax on the use of state-owned subsoil is transferred to the BTSEE budget since subsurface use causes environmental damage at the local level.

There is a need to introduce several additional taxes, namely: a) from businesses that manage the disposal or storage of waste within the community; b) for the use of local natural resources - areas of forest and water resources, extraction of local minerals (sand, gravel, fertile soil, peat, etc.), in case of their removal outside the district [25].

Critical analysis of the fiscal equalization system proved that its main disadvantages are a real threat to BSTEE's. The analysis of the fiscal equalization system introduced in 2014 instead of the system of income and expenditure balancing allowed us to conclude that the current system is also not without disadvantages. The main one is the reverse subsidy, which amount is determined based on individual income tax. It negatively affects the financial position of a BSTEE, since the personal income tax itself is the main source of the community's income. We put forward a hypothesis regarding the definition of reverse subsidy's permissible limits correlated to BSTEE per capita income growth rates. It was demonstrated that the exponential law could be considered as an intricate model since it does 
not reflect with sufficient accuracy the dynamics of BSTEE income growth. It was suggested to use the so-called soft model to describe BSTEE own income dynamics by the logistic curve. This model allows determining the safe limits of BSTEE financial position adjustments and ensures its sustainable development. The lower and upper points of the logistic curve's trajectory could be considered as these limits.

A detailed analysis of sustainable development opportunities at the level of local communities illuminates the problems of education and raising awareness. In this context, the use of information technology can help both entrepreneurship and investment and promote the principles of sustainable development and mitigate the consequences of climate changes and popularization of BTSEE and raise awareness of investors and stakeholders about the territory.

Previous research $[25,26]$ proposed a methodology for community analysis to identify the needs, wants, and gaps for strategy development. Generally, we proposed dividing it into four steps, which we now believed should be improved to include climate change issues.

Step 1. Scope - Initial analysis based on available data (geography, finances, including what taxes remain in the community, economic indicators, businesses, online reviews...). This step also includes the estimation of consequences of climate change for the territory - because they vary in terms of geographical characteristics. Also on this step, the local (regional) Networked Readiness Index could be developed based on the international methodology proposed by the World Economic Forum. The index, referred to as Technology Readiness, measures the welfare of territories to exploit the opportunities offered by information and communications technology (ICT).

Step 2. Communication - the first stage of communication with stakeholders. Numerous questions arise. What information is available and what (in their opinion) is missing? What are the expectations, what are the problems, how they see the opportunities and what they would like to have (money is not the answer, here we should try to understand their vision - agro, services, tourism...) and how we can mitigate the negative impact of climate changes or can we benefited in some areas from that changes. All information could be visualized (table 1).

Table 1

Template for identifying groups of stakeholders

\begin{tabular}{|l|l|l|l|l|}
\hline \multicolumn{1}{|c|}{$\begin{array}{c}\text { Stages of the policy } \\
\text { integration }\end{array}$} & $\begin{array}{c}\text { Stakeholders } \\
\text { groups }\end{array}$ & $\begin{array}{c}\text { The } \\
\text { influence } \\
(+/-)\end{array}$ & $\begin{array}{c}\text { How to reach } \\
\text { stakeholders? }\end{array}$ & $\begin{array}{c}\text { How do you } \\
\text { understand that your } \\
\text { communication is } \\
\text { effective? }\end{array}$ \\
\hline $\begin{array}{l}\text { Stage 1: Setting a green } \\
\text { agenda }\end{array}$ & & & \\
\hline $\begin{array}{l}\text { Stage 2: Weighing policy } \\
\text { options }\end{array}$ & & & \\
\hline $\begin{array}{l}\text { Stage 3: Making decisions } \\
\text { and marketing reform }\end{array}$ & & & \\
\hline $\begin{array}{l}\text { Stage 4: Implementing } \\
\text { reform the smart way }\end{array}$ & & & \\
\hline $\begin{array}{l}\text { Stage 5: Tracking and } \\
\text { assessing reform impacts }\end{array}$ & & & \\
\hline
\end{tabular}

Stages 1 and 2 analyze the community and identify the most promising areas of development and possible growth points while assessing opportunities for implementation infrastructure, finance, specialists (availability and who can be involved). It will also be clear what kind of information technologies can be applied now that need development. 
If necessary, a few more meetings and consultations can be held to clarify and form a common opinion.

Stage 3. Summarizing - the descriptive part is what we have now and the good part is what can be changed in the short term. Includes also representing part - what can be offered to investors and a list of potential initiatives that the region may be interested in (manufacturing, international communities...)

Step 4. Action plan (to further develop the strategy) - a list of specific steps and their sequence to determine where to get money, who to contact, etc.

Summarizing, let's say that in an optimistic scenario, the implementing of informational technology in BTSEE planning process can initiate and develop such things are:

- raise the standards of living in the community and increase the level of employment;

- create a platform for dialogue and involvement of the population in discussing problems (forming a public inquiry) and finding solutions, especial in so urgent but unpopular (or at least not understandable in short-run) issues like combating climate changes [27, 28];

- attracting investment in BTSEE and creating new businesses through digitalization and increasing transparency of the processes and cutting the time for starting projects and business;

- the creation of a positive image of the territory in the country on the international market can give impetus for economic development.

BTSEE could be interpreted as the basis of local self-government and the designing of an effective system of financial capacity at different levels since the national economy is also formed at the basic territorial level using information technology.

Therefore, forming an effective model for the development of BTSEE required considering the specifics of interactions of the local economy and urgent national (regional) economic processes. Undoubtedly, one of the critical processes is the choice of specialization. The other - the design of a territorial brand based on the use of territorial advantages and resources. Resources are an integral value and a unique component that combines natural, human, infrastructural, and more.

Conclusions. The paper proposes methodological approaches for informational and analytical support for decision-making on sustainable development of local territorial entities (for example, united territorial communities, BTSEE). It is emphasized that the climate change forecast must be implemented to local, territorial development strategies. In particular, in Ukraine, these are strategies for developing united territorial communities, which were formed (876 communities in May this year) and continue to be formed. In total, the government plans to create 1.356 BTSEEs, which should cover over $87 \%$ of Ukraine's territory. This means that integrating the features of territorial development, climate change and the dynamics of human potential will be developed and strengthened. The way of implementation is that the territorial development strategies take into account changes in the functional purpose of the territories and determine the directions of prospective activity, taking into account changes in agroclimatic and infrastructural conditions of development. For this purpose, it is proposed to create a complex of information and analytical support for the sustainable development of local, territorial entities.

According to our calculations, the permissible value of the reverse subsidy should be no more than $25 \%$. It was demonstrated that it is possible to enable the sustainable development of financially capable communities if a flexible, financially based approach is used to determine the reverse subsidy's amount.

The customer (investor) of such a product may be the association of BTSEE executives, such as the Association of Ukrainian Cities, the Association of United Territorial 
Communities, and individuals. Implementing the proposed mechanisms for the sustainable development of the BTSEE involves active consultation with local leaders and government representatives in charge of government decentralization.

\section{References}

1. Baller, S., Dutta, S. \& Lanvin, B. (2016). "The global information technology report 2016. Innovating in the Digital Economy" World Economic Forum.

2. Mearns, L. O., Lettenmaier, D. P. \& McGinnis, S. (2015). Uses of Results of Regional Climate Model Experiments for Impacts and Adaptation Studies: the Example of NARCCAP. Current Climate Change Reports, 1, 1-29.

3. Jeremy, S. L. (2018). Drought and Fire in the Western USA: Is Climate Attribution Enough? Current Climate Change Reports, 4 (4), 396-406.

4. Henry, W. B. \& Krutz, L. J. (2016). Water in Agriculture: Improving Corn Production Practices to Minimize Climate Risk and Optimize Profitability. Current Climate Change Reports, 2, 49-54.

5. Biasutti, M. (2019). Rainfall trends in the African Sahel: Characteristics, processes, and causes. Wiley Interdisciplinary Reviews: Climate Change, 10 (4).

6. Yeager, S. G. \& Robson, J. I. (2017). Recent Progress in Understanding and Predicting Atlantic Decadal Climate Variability. Current Climate Change Reports, 3, 112-127

7. Wu, R., You, T. \& Hu, K. (2019). What Formed the North-South Contrasting Pattern of Summer Rainfall Changes over Eastern China? Current Climate Change Reports, 2, 47-62.

8. Pascale, S., Carvalho, L. M. V. \& Adams, D. K. (2019). Current and Future Variations of the Monsoons of the Americas in a Warming. Current Climate Change Reports, 2, 125-144.

9. Cook, K. H. \& Vizy, E. K. (2019). Contemporary Climate Change of the African Monsoon Systems. Current Climate Change Reports September, 3, 145-149.

10. Chowdary, J. S., Hu, K., Srinivas, G., Kosaka, Yu., Wang, L. \& Koteswara Rao, K. (2019). The Eurasian Jet Streams as Conduits for East Asian Monsoon Variability. Current Climate Change Reports 5 (3), 233-244.

11. Cherchi, A., Ambrizzi, T. \& Behera, S. (2018). The Response of Subtropical Highs to Climate Change. Current Climate Change Reports, 4 (4), 371-382.

12. Favier V., Krinner, G. \& Amory, Ch. (2017). Antarctica-Regional Climate and Surface Mass Budget. Current Climate Change Reports, 3 (4), 303-315.

13. Seager, R. \& Ting, M. (2017). Decadal Drought Variability Over North America: Mechanisms and Predictability. Current Climate Change Reports. 3 (2), 141-149.

14. Soares, M. B. \& Buontempo, C. (2019). Challenges to the sustainability of climate services in Europe. Wiley Interdisciplinary Reviews: Climate Change, 10 (4).

15. Chand, S. S., Dowdy, A. J., Ramsay, H. A., Walsh, K. J. E., Tory, K. J., Power, S. B., Bell, S. S., Lavender, S. L., Hua, Ye. \& Kuleshov, Yu. (2019). Review of tropical cyclones in the Australian region: Climatology, variability, predictability, and trends. Wiley Interdisciplinary Reviews: Climate Change. 10 (4).

16. Rahman, M., Ahmad, S., Mahmud, A., Hassan-uz-Zaman, Md., Nahian, M., Ahmed, A., Nahar, Q. \& Streatfield, P. (2019). Health consequences of climate change in Bangladesh: An overview of the evidence, knowledge gaps and challenges. Wiley Interdisciplinary Reviews: Climate Change, 10 (4).

17. Vaughan, C., Hansen, J., Roudier, P., Watkiss, P. \& Carr, E. (2019). Evaluating agricultural weather and climate services in Africa: Evidence, methods, and a learning agenda. Wiley Interdisciplinary Reviews: Climate Change, 10 (4).

18. Biasutti, M. (2019). Rainfall trends in the African Sahel: Characteristics, processes, and causes. Wiley Interdisciplinary Reviews: Climate Change. 10 (4).

19. Danilova, N. V. (2018). Evaluation of the influence of climate change on the productivity of millet in the central part of Ukraine. Ukrainian hydrometeorological journal, 21, 35-41.

20. Boichuk, D., Skynyk, O., Sidenko, V., Aguilar, E. \& Skrynyk, O. (2018). Extreme air temperature in Ukraine: data rescue, homogenization and trend analysis. https://doi.org/10.13140/RG.2.2.10551.16809 
21. Osadchyi, V., Skynyk, O., Radchenko, R., Skrynyk, O. \& Skrynyk, O. (2018). Homogenization of Ukrainian air temperature data. International Journal of Climatology, 38 (1), 497-505.

22. Rockel, B. (2015). The Regional Downscaling Approach: a Brief History and Recent Advances. Current Climate Change Reports, 1, 22-29.

23. Luca A., Elia, R. \& Laprise, R. (2015). Challenges in the Quest for Added Value of Regional Climate Dynamical Downscaling. Current Climate Change Reports, 1, 10-21.

24. Danko, Y. (2017). Competitive principles of sustainable rural development. Regional Economics, 3, 70-76.

25. Horoshkova, L. A., Volkov, V. P., Khlobystov, Ye. V. \& Kutyk, V. V. (2019). Prohnostychni modeli finansovoho rehuliuvannia biudzhetiv terytorialnykh hromad. [Prognostic models of financial regulation of budgets of territorial communities]. Ekonomichnyi visnyk universytetu: Zbirnyk naukovykh prats uchenykh ta aspirantiv. - Pereiaslav-Khmelnytskyi: Pereiaslav-Khmelnytskyi derzhavnyi pedahohichnyi universytet im. H.Skovorody - Economic Bulletin of the University: Collection of scientific works of scientists and graduate students. - Pereyaslav-Khmelnytsky: Pereyaslav-Khmelnytsky State Pedagogical University named after G. Skovoroda, 42, 179-190. Retrieved from https://economic-bulletin.com/index.php/journal/article/view/573/602.

26. Horoshkova, L. A., Khlobystov, Ye. V. \& Trofymchuk, V. O. (2018). Finansovi mekhanizmy staloho vykorystannia terytorialnykh resursiv pryrodno-hospodarskykh system. [Financial mechanisms of sustainable use of territorial resources of natural economic systems]. Teoretychni $i$ praktychni aspekty ekonomiky ta intelektualnoi vlasnosti: zbirnyk naukovykh prats. Mariupol: DVNZ "PDTU" - Theoretical and practical aspects of economics and intellectual property: a collection of scientific papers. Mariupol: SHEI "PDTU", 18, 275-284. Retrieved from http://tpa.pstu.edu/article/view/180117/180061

27. Zharova, L. (2019). Sustainable development in smart city initiatives concepts. Economics and Law, 3 (54), 107-114.

28. Dey, R., Lewis, S. C., Arblaster, J. M., Abram, N. J. (2019). A review of past and projected changes in Australia's rainfall. Wiley Interdisciplinary Reviews: Climate Change. 10 (3).

29. Samset, B. H., Stjern, C. W., Andrews, E., Kahn, R. A., Myhre1, G., Schulz, M. \& Schuster, G. L. (2018). Aerosol Absorption: Progress Towards Global and Regional Constraints. Current Climate Change Reports, 4, 65-83.

Manuscript received 18 March 2021

Mechanism of Economic Regulation, 2021, No 2, 5-15

ISSN 1726-8699 (print)

Інформаційні технології як інструмент реалізації Цілей сталого розвитку на місцевому рівні

\section{ЛЮБОВ ВАЛЕРІЇвНА ЖАРОВА*, $\Theta_{\text {ВГЕН ВоЛОДИМИРОвИч ХЛОБИСтов }}{ }^{* *}$}

* докторка економічних наук, завідувачка кафедри міжнародних економічних відносин, бізнесу та менеджменту, Украйнсько-американський університет Конкордія, вул. Тургенєвська 8-14, м. Київ, Україна;

професорка Університету економіки та гуманітарних наук, вул. Сікорського, 4, м. Бельсько-Бяла, Польща,

тел. +38 (050) 550-93-02, e-mail: zharova.l@gmail.com;

** доктор економічних наук, професор, професор кафедри екології

Національного університета "Кисво-Могилянська академія», вул. Г.Сковороди 2, корп.3. м. Київ;

професор Університету економіки та гуманітарних наук, 
Liubov V. Zharova, Ievgen V. Khlobystov.

Informational Technologies as a Tool for Local Level Sustainable Development Goals Implementation

вул. Сікорського, 4, м. Бєльсько-Бяла, Польща,

тел.+380-66-221-01-99, e-mail: ievgen.khlobystov@ukr.net,ievgen.khlobystov@ukma.edu.ua

Проведене дослідження ілюструє міждисциплінарний підхід до сталого розвитку місцевих громад шляхом впровадження новітніх інноваційних підходів та заповнення прогалин сучасними технологічними можливостями. Центральною гіпотезою цього дослідження $\epsilon$ те, що конкурентоспроможності та ефективності економічного розвитку місцевих громад можна досягти в рамках боротьби зі змінами клімату за допомогою впровадження інформаційних технологій на всіх етапах - від планування до реалізації. У статті підкреслено, що прогноз зміни клімату повинен бути реалізований відповідно до стратегій місцевого територіального розвитку. Шлях реалізації полягає у тому, що стратегії територіального розвитку враховують зміни функціонального призначення територій та визначають напрями перспективної діяльності, враховуючи зміни в агрокліматичних та інфраструктурних умовах розвитку. Із цією метою пропонується створити комплекс інформаційно-аналітичного забезпечення сталого розвитку місцевих, територіальних утворень. Допустиме значення зворотної субсидії, за нашими розрахунками, має становити не більше $25 \%$. Було продемонстровано, що можна забезпечити стійкий розвиток фінансово спроможних громад, якщо для визначення суми зворотної субсидії використовувати гнучкий фінансовий підхід.

Ключові слова: зелена економіка, цілі сталого розвитку, економічні тенденції, децентралізація, міжнародна економіка.

JEL Codes: O21, Q01

Tables: 1, Figures: 1, References: 29

Language of the article: English 